\title{
ANALISIS PENGARUH POLUSI UDARA, KEBISINGAN, DAN GETARAN DI PINTU TOL LINGKAR LUAR JAKARTA TERHADAP KENYAMANAN SERTA PERFORMA KOGNITIF OPERATOR
}

\author{
Erlinda Muslim ${ }^{1}$, Danu Hadi Syaifullah ${ }^{2}$, Viky Muruatut Toyyibah ${ }^{3}$ \\ Fakultas Teknik, Departemen Teknik Industri, UI \\ Depok 16424 \\ Email: ${ }^{1}$ erlinda@eng.ui.ac.id, ${ }^{2}$ danuhadi@ui.ac.id, ${ }^{3}$ vikymuruatut@ outlook.com
}

\begin{abstract}
ABSTRAK
Jalan tol atau yang biasa disebut sebagai jalan bebas hambatan adalah alternatif untuk mengatasi kemacetan lalu lintas dan mempersingkat jarak dari suatu tempat ke tempat lainnya. Jumlah kendaraan yang lalu lang di jalan tol terus meningkat setiap tahunnya. PT Jasa Marga Tbk mengungkapkan bahwa jumlah kendaraan yang melewati jalan tol pada tahun 2013 mencapai 1257,42. Tingginya volume kendaraan ini tentunya sangat mempengaruhi kondisi lingkungan di pintu tol. Kondisi lingkungan di pintu tol yang buruk membuat operator berpotensi merasa tidak nyaman sehingga mempengaruhi performa kerja. Penelitian ini bertujuan untuk melihat pengaruh polusi udara, kebisingan, dan getaran yang dianggap sebagai faktor lingkungan paling mengganggu, dengan menggunakan peralatan Haz dust IV, Noise Dosimeter, HVM 100, time study, dan kuisioner. Dengan menggunakan metode statistik regresi linear berganda, diperoleh ketiga faktor lingkungan berbanding lurus dengan waktu transaksi operator (time study), dimana polusi udara merupakan faktor yang paling signifikan secara statistik diikuti oleh getaran dan kebisingan.
\end{abstract}

Kata kunci: Ergonomi, Kebisingan, Operator Pintu Tol, Polusi Udara, Time Study, Whole-body Vibration

\section{Pendahuluan}

Faktor manusia sebagai pelaku utama pelayanan pintu tol memegang peranan penting dalam upaya peningkatan kualitas pelayanan. Namun, permasalahan mengenai faktor manusia dalam perancangan sistem kerja seringkali kurang menjadi perhatian. Padahal kondisi stasiun kerja pintu tol yang kurang ergonomis akan berakibat pada bahaya tenaga kerja, kesehatan pekerja yang memburuk, cacat, dan pada akhirnya mengurangi produktivitas pekerja dan kualitas pekerjaan/produk dan meningkatkan biaya (Ashraf, 2003). ${ }^{[19]}$ Solusi untuk mengatasi masalah-masalah tersebut adalah dengan merancang sistem kerja yang ergonomis. Salah satu faktor yang terdapat dalam merancang sistem kerja yang ergonomis adalah kondisi lingkungan yang berinteraksi dengan pekerja.

Penelitian Li Lan et al. (2010) menunjukan bahwa produktivitas memiliki hubungan yang sangat erat dengan kualitas lingkungan (temperatur, kebisingan, cahaya, dll.). ${ }^{[7]}$ Berdasarkan data hasil kuisioner yang disebarkan pada 53 operator gerbang tol (28 pria dan 25 wanita), polusi udara, kebisingan, dan getaran merupakan tiga unsur lingkungan yang memiliki level gangguan yang mengganggu dan sangat mengganggu sehingga dijadikan fokus pada penelitian ini.

Polusi udara memiliki dampak terhadap perilaku kognitif seseorang karena tubuh manusia membutuhkan banyak oksigen dan apabila oksigen yang dihirup memiliki kualitas yang buruk maka akan mempengaruhi kinerja tubuh (Clark dan Sokoloff, 1999). ${ }^{[8]}$ Penelitian sebelumnya mendemonstrasikan bahwa kebisingan tempat kerja (misalnya kemacetan) dapat mengganggu memori (Smith dan Miles, 1987),konsentrasi (Smith, 1991) dan kinerja (Smith, 1988). ${ }^{[3]}$ Tidak hanya kualitas udara dan kebisingan, getaran pun memiliki tingkat kepentingan yang signifikan. Pada penelitian ini, getaran yang dianalisis merupakan getaran seluruh tubuh. Efek getaran jenis ini terhadap kesehatan adalah gangguan terhadap tulang pinggang dan sistem saraf yang berhubungan (Seidel \& Heide 1986; Griffin 1990). Penelitian yang dilakukan oleh Kelsey (1984) menunjukan bahwa penyakit gangguan tulang pinggang merupakan penyebab utama yang membatasi aktivitas fisik dan penyebab utama pekerja tidak dapat hadir di tempat kerjanya. ${ }^{[20]}$

Alasan-alasan di atas menjadikan analisis pengaruh polusi udara, kebisingan, dan getaran terhadap kenyamanan serta performa kognitif operator, khususnya operator pintu tol Lingkar Luar Jakarta, menjadi penting. Metode statistik regresi linear berganda digunakan untuk menganalisis faktor lingkungan yang memiliki pengaruh paling signifikan secara statistik pada performa hingga pada akhirnya dapat diketahui hubungan antara setiap faktor lingkungan terhadap performa kognitif operator. 


\subsection{Ergonomi}

Ergonomi berunjuk pada hubungan yang kompleks antara pekerja dan pekerjaan mereka yang mencakup setiap aspek tempat kerja. Ergonomi berfokus pada manusia dan interaksinya dengan produk, peralatan, fasilitas, prosedur dan lingkungan yang digunakan dalam pekerjaan dan kehidupan sehari-hari (McCormick, 1993). ${ }^{[1]}$

Ergonomi, sebagai salah satu disiplin ilmu, memiliki dua tujuan utama. Pertama ialah untuk meningkatkan efektivitas dan efisiensi pekerjaan dan aktivitas yang dilakukan. Termasuk didalamnya ialah meningkatkan kenyamanan dalam penggunaan alat, mengurangi tingkat kesalahan, dan meningkatkan produktivitas. Tujuan kedua ialah untuk meningkatkan nilai manusia tertentu, termasuk meningkatkan keamanan, mengurangi kelelahan dan stres, meningkatkan kenyamanan, meningkatkan kepuasan dalam bekerja, dan meningkatkan kualitas kehidupan. ${ }^{[18]}$

\subsection{Pencemaran Udara}

Pencemaran udara/polusi udara merupakan campuran dari suatu atau lebih bahan pencemar, baik berupa padatan, cairan, atau gas yang masuk terdispersi ke udara dan kemudian menyebar ke lingkungan sekitarnya. Pencemaran udara merupakan masalah kesehatan utama yang mempengaruhi seseorang baik pada negara berkembang maupun negara maju. Pada tahun 2013, penilaian yang dilakukan oleh International Agency for Research on Cancer (IARC) WHO menyimpulkan bahwa polusi udara bersifat karsinogenik untuk manusia, dengan komponen partikel (seperti PM10 atau yang berukuran lebih kecil) berkorelasi erat dengan peningkatan insiden kanker, khususnya kanker paru-paru. ${ }^{[12]}$

Particulate Matter (PM) mempengaruhi kesehatan manusia lebih banyak dibandingkan polusi lain. Komponen utama PM ialah sulfat, nitrat, ammonia, sodium klorida, karbon hitam, debu mineral dan air. PM meliputi campuran kompleks dari partikel padat dan cair zat organik dan nonorganik yang tersebar di udara. Ada dua jenis PM, yakni partikel halus (PM2.5) dan partikel debu kasar (PM10). Kedua partikel tersebut merupakan jenis partikel yang paling banyak memberikan dampak buruk karena dapat masuk dan tersangkut di dalam paru-paru. Pemaparan partikel yang kronis memiliki risiko berkembangnya penyakit kardiovaskular dan pernapasan, juga kanker paru-paru. ${ }^{[1]}$

Dalam rangka menjaga produktivitas dan kesehatan pekerja terkait dengan pencemaran udara, pemerintah mengeluarkan peraturan mengenai Nilai Ambang Batas Faktor Fisika dan Faktor Kimia di Tempat Kerja. Batas partikulat inhalabel (PM10) ialah $3 \mathrm{mg} / \mathrm{m} 3$. ${ }^{[1]}$

\subsection{Kebisingan}

Kebisingan adalah suara yang berlebihan atau yang tidak dikehendaki sehingga berpotensial menimbulkan gangguan dan/atau kerusakan pendengaran (berasal dari pekerjaan dan/atau sumber non-pekerjaan) (Chiovenda, 2007). Kebisingan kendaraan merupakan salah satu tipe kebisingan yang meluas dan pada umumnya dianggap lebih mengganggu dibandingkan tipe kebisingan seperti industri dan komunitas (Nejadkoorki dan Naseri, 2009). ${ }^{[16]}$

Kebisingan kendaraan bergantung pada tiga hal:

1. Volume kendaraan - Semakin banyak kendaraan akan semakin bising.

2. Kecepatan kendaraan - Semakin cepat kendaraan akan semakin bising.

3. Persentase truk berat di jalan - Truk berat. ${ }^{[23]}$

Secara umum, dampak dari kebisingan terhadap kesehatan manusia dapat dikelompokan menjadi dampak secara auditori dan nonauditori. Secara auditori, paparan kebisingan dalam jangka waktu yang lama dapat menuntun pada kerusakan sel rambut atau organ Corti dan pada akhirnya akan menyebabkan hilangnya pendengaran khususnya pada frekuensi sekitar 4 $\mathrm{kHz}$ (Chao, 2013). Dampak nonauditori diawali karena kebisingan mempengaruhi organ selain organ pendengaran, menyebabkan fungsi organ menjadi abnormal dengan merangsang autonomic nervous system (ANS) dan korteks tulang belakang. Pada akhirnya mengakibatkan jantung berdetak cepat, tekanan darah tinggi, kontraksi otot yang berimbas pada kelelahan, dan mereduksi sensitivitas mata terhadap cahaya. ${ }^{[20]}$

Dalam rangka menjaga produktivitas dan kesehatan pekerja terkait dengan kebisingan di tempat kerja nya, pemerintah mengeluarkan peraturan mengenai Nilai Ambang Batas Faktor Fisika dan Faktor Kimia di Tempat Kerja. Untuk pekerjaan selama 8 jam, batas kebisingan ialah $85 \mathrm{~dB} \cdot{ }^{[17]}$

\subsection{Getaran}

Proses industrialisasi dan modernisasi teknologi selalu disertai mesin-mesin atau alat-alat mekanis lain yang dijalankan oleh mesin. Sebagian dari kekuatan mekanik ini disalurkan kepada tubuh pekerja sehingga perlu diketahui lebih lanjut mengenai efek buruk dan batas-batas getaran yang aman bagi tenaga kerja. Getaran mekanik dibedakan menjadi:

1. Getaran seluruh tubuh (whole-body vibration): Getaran yang mempengaruhi hampir keseluruhan bagian tubuh dan terjadi ketika pekerja duduk atau berdiri pada lantai atau kursi yang bergetar. Operator truk, bis, dan traktor merupakan contoh pekerjaan yang memiliki risiko terkena whole-body vibration. 
2. Getaran alat lengan (hand-arm vibration): Getaran masuk ke dalam tubuh manusia melalui organ yang bersentuhan dengan peralatan yang bergetar. Contohnya ialah ketika seorang operator menggunakan alat seperti gergaji atau bor listrik dimana getaran mempengaruhi tangan.

Risiko terkenanya cidera akibat getaran bergantung pada intensitas dan frekuensi getaran, waktu rata-rata pemaparan dan bagian tubuh yang terpapar getaran. Menurut Suma'mur (1988) dalam bukunya yang berjudul Higiene Perusahaan dan Kesehatan Kerja, terdapat tiga tingkat efek dari getaran, yakni gangguan kenikmatan, terganggunya pengerjaan tugas dan cepat timbul kelelahan, dan bahaya terhadap kesehatan. ${ }^{[6]}$

Dalam rangka perlindungan tenaga kerja terhadap timbulnya risiko bahaya akibat pemaparan getaran, pemerintah mengeluarkan peraturan tentang Nilai Ambang Batas Faktor Fisika dan Faktor Kimia di Tempat Kerja. Adapun peraturan untuk getaran seluruh tubuh ialah sebesar 0,5 meter per detik kuadrat $(\mathrm{m} / \mathrm{s} 2) .{ }^{[17]}$

\subsection{Jalan Tol}

Jalan tol adalah jalan umum yang kepada pemakainya dikenakan kewajiban membayar tol dan merupakan jalan alternatif lintas jalan umum yang telah ada. Jalan tol diselenggarakan dengan maksud untuk mempercepat pewujudan jaringan jalan dengan sebagian atau seluruh pendanaan berasal dari pengguna jalan untuk meringankan beban pemerintah. Selain itu, gardu tol juga merupakan ruang tempat bekerja pengumpul tol untuk melaksanakan tugas pelayanan kepada pemakai jalan tol.[15] Adapun Waktu pelayanan yang terdapat di pintu tol saat melakukan transaksi dipengaruhi oleh tarif tol, nominal pembayaran, kesiapan dalam pembayaran, jenis ukuran dan muatan (berat) kendaraan. ${ }^{[2]}$

\subsection{Multiple Regression Linear/ Regresi Linear Berganda}

Analisis regresi linear merupakan teknik statistik yang dapat digunakan untuk menganalisis hubungan antara dependen (ukuran) dan variabel independen (prediktor). Tujuan dari analisis regresi berganda adalah untuk menggunakan variabelvariabel independen yang nilainya sudah diketahui untuk memprediksi suatu nilai dependen yang dipilih oleh peneliti. Setiap variabel independen diberikan bobot oleh prosedur analisis regresi untuk memastikan prediksi yang maksimal dari sekelompok variabel independen. Inilah yang disebut sebagai persamaan regresi, yakni suatu kombinasi linear dari variabel independen yang terbaik untuk memperkirakan variabel dependen.

Isu utama adalah dalam menghitung koefisien regresi dan memprediksi variabel dependen, asumsi dari analisis regresi harus dipenuhi. Asumsi-asumsi yang harus diuji, meliputi linearitas, varians dari error yang konstan (homoskedastisitas), error yang bebas, dan distribusi normal dari error. ${ }^{[16]}$

\section{Metode Penelitian}

\subsection{Teknis Pengukuran Langsung}

Pengambilan data langsung terbagi menjadi lima bagian, yakni pengukuran polusi udara, kebisingan, getaran seluruh tubuh, waktu transaksi operator, dan identifikasi kenyamanan operator.

Pengukuran polusi udara yang dalam penelitian ini ialah PM10 menggunakan Haz-Dust IV. Bersumber dari buku "Handbook of Human Factors and Ergonomics Method" pengukuran polusi udara dilakukan selama 15 menit dimana alat Haz Dust IV diletakkan sejauh $30 \mathrm{~cm}$ dari hidung dan mulut operator. ${ }^{[21]}$

Pengukuran kebisingan untuk menilai paparan terhadap operator secara personal menggunakan noise dosimeter. ${ }^{[13]}$ Sifat kebisingan yang disebabkan oleh kendaraan ialah kontinyu dan berulang sehingga memungkinkan untuk mengukur hanya selama 20 menit dan disimpulkan untuk 8 jam kerja (Tiziana Caciari, 2013). ${ }^{[1]}$

Pada buku Handbook of Human Factors and Ergonomics Method dinyatakan untuk mengukur besar whole-body vibration yang terpapar pada seorang pekerja, pad dari alat ukur (HVM 100) diletakkan di tempat duduk operator. Lama pengukuran sendiri minimum selama 2-5 menit sehingga nilai yang didapatkan bersifat signifikan secara statistik. ${ }^{[21]}$ Pengukuran time study dilakukan dengan merekam menggunakan kamera handphone selama 20 menit. 
Tabel 1. Perbandingan tingkat polusi udara, kebisingan, dan getaran

\begin{tabular}{|c|c|c|c|c|}
\hline Variabel & Waktu & Veteran & Rorotan & Pondok Ranji \\
\hline $\begin{array}{c}\text { Polusi } \\
\left(\mathbf{m g} / \mathbf{m}^{3}\right)\end{array}$ & $07.00-09.00$ & 0.12 & 0.4 & 0.10 \\
\cline { 2 - 5 } & $10.00-12.00$ & 0.32 & 0.43 & 0.42 \\
\hline $\begin{array}{c}\text { Kebisingan } \\
(\mathbf{d B})\end{array}$ & $07.00-09.00$ & 80.6 & 81.6 & 80.1 \\
\cline { 2 - 5 } & $10.00-12.00$ & 83.4 & 83.1 & 86.7 \\
\hline $\begin{array}{c}\text { Getaran } \\
\left(\mathbf{m} / \mathbf{s}^{\mathbf{2}}\right)\end{array}$ & $07.00-09.00$ & 0.0838 & 0.0776 & 0.0671 \\
\cline { 2 - 5 } & $10.00-12.00$ & 0.099 & 0.0854 & 0.0982 \\
\hline
\end{tabular}

Pengukuran kenyamanan pada penelitian ini dilakukan secara kuantitatif dan kualitatif. Pengukuran kuantitatif dilakukan dengan membandingkan faktor-faktor lingkungan yang terdapat di tempat kerja dengan Nilai Ambang Batas Faktor Fisika dan Faktor Kimia di Tempat Kerja. Sedangkan pengukuran kualitatif dilakukan dengan membagikan kuisioner yang bereferensi dari dua puluh Unipolar Scale ${ }^{[10]}$ dan juga dengan melakukan wawancara langsung dengan setiap operator.

\subsection{Lokasi dan Waktu Pengambilan Data}

Terdapat tiga lokasi yang dijadikan tempat untuk pengambilan sampel, yakni Rorotan, Veteran, dan Pondok Ranji. Pemilihan tempat didasarkan pada pertimbangan volume kendaraan dan kondisi lingkungan. Selain itu, pengambilan data dilakukan pada tanggal 3-18 April 2014 dan jam 10-12 siang karena pada waktu tersebut kondisi lingkungan lebih buruk dibandingkan pada pagi hari seperti yang ditunjukkan pada Tabel 1.

Heading pada level ketiga mengikut style dari heading level kedua. Hindari penggunaan heading lebih dari tiga level.

\subsection{Jumlah Sampel}

Tingkat error ditetapkan oleh peneliti sebesar 5\%. Dengan demikian, jumlah sampel yang diperlukan dalam penelitian ini dapat dilihat pada Tabel 2 .

Tabel 2. Jumlah sampel berdasarkan lokasi pengambilan data

\begin{tabular}{|l|l|l|}
\hline Pintu Tol & Jumlah Populasi & Jumlah Sampel \\
\hline Rorotan & 17 & 16 \\
\hline Veteran & 16 & 15 \\
\hline Pondok Ranji & 16 & 15 \\
\hline
\end{tabular}

Sebelum menentukan jumlah sampel, terlebih dahulu dilakukan seleksi jumlah operator yang sesuai dengan kriteria yang ditentukan. Kriteria tersebut ialah:

1. Operator telah bekerja minimal selama 4 tahun. Pekerja yang telah bekerja dalam kurun waktu lebih dari 4 tahun memiliki perubahan kemampuan pendengaran bahkan dalam tingkat kebisingan yang rendah. ${ }^{[1]}$

2. Berada dalam kondisi tubuh yang sehat, tidak memiliki penyakit akut.

3. Operator yang dijadikan responden ialah operator shift 1 yang bekerja mulai dari jam 6 pagi hingga 1 siang. Mengingat adanya gangguan cuaca pada bulan April 2014 yakni turun hujan di atas jam 12 siang.

Setelah itu, perhitungan jumlah sampel data yang diambil ialah dengan formula 3.1 sebagai berikut:

$$
n=\frac{N}{1+N(e)^{2}}
$$

Formula tersebut merupakan formula yang dibuat oleh Yamane dengan $\mathrm{n}$ ialah banyaknya jumlah sampel, $\mathrm{N}$ ialah banyaknya populasi, dan e tingkat kesalahan yang dipilih. Banyaknya populasi ialah operator yang berada di setiap pintu tol, sehingga perhitungan jumlah sampel dilakukan secara terpisah berdasarkan pintu tolnya. 


\section{Hasil dan Pembahasan}

Tabel 3. Koefisien model regresi linear

\begin{tabular}{|c|c|c|c|c|c|}
\hline & \multicolumn{3}{|c|}{ Coefficient $^{\mathrm{a}}$} & \multirow[b]{3}{*}{$\mathrm{t}$} & \multirow[b]{3}{*}{ Sig. } \\
\hline \multirow[b]{2}{*}{ Model ${ }^{-}$} & \multicolumn{2}{|c|}{$\begin{array}{l}\text { Unstandardized } \\
\text { Coefficients } \\
\end{array}$} & $\begin{array}{l}\text { Standardized } \\
\text { Coefficients }\end{array}$ & & \\
\hline & $\mathrm{B}$ & Std. Error & Beta & & \\
\hline $1 \quad$ (Constant) & .936 & 3.778 & & .248 & .806 \\
\hline Kebisingan & .026 & .044 & .081 & .598 & .553 \\
\hline Getaran & 1.467 & 1.618 & .108 & .907 & .370 \\
\hline PolusiLog & 1.459 & .468 & 490 & 3.115 & .003 \\
\hline WaktuTransaksiLag & .190 & .149 & 183 & 1.277 & .209 \\
\hline
\end{tabular}

a. Dependent Variable : WaktuTransaksi

\subsection{Performa}

Hasil pengolahan data hubungan antara faktor lingkungan dengan performa operator berdasarkan regresi linear berganda pada Tabel 3 menunjukkan bahwa model regresi pada penelitian ini ialah.

$$
\mathrm{y}=0,936+0,026 \mathrm{X}_{1}+1,467 \mathrm{X}_{2}+1,459 \mathrm{X}_{3}
$$

Di mana:

$$
\begin{array}{ll}
\mathrm{y} & =\text { Waktu transaksi operator }(\mathrm{s}) \\
\mathrm{X}_{1} & =\text { Kebisingan }(\mathrm{dB}) \\
\mathrm{X}_{2} & =\text { Getaran }(\mathrm{m} / \mathrm{s} 2) \\
\mathrm{X}_{3} & =\text { Polusi udara }(\mathrm{mg} / \mathrm{m} 3)
\end{array}
$$

Polusi udara memiliki hubungan yang positif dengan waktu transaksi operator pintu tol. Polusi udara memiliki nilai koefisien sebesar 1,459 yang artinya setiap pertambahan $1 \mathrm{mg} / \mathrm{m} 3$ pada kadar PM10 di udara, mengakibatkan kenaikan dalam waktu transaksi sebesar 1,459 sekon. Apabila dilihat dari nilai koefisien beta, polusi udara memiliki tingkat pengaruh yang paling signifikan dibandingkan faktor lingkungan lain, sebesar 0,490. Pengaruh dari polusi udara terhadap waktu transaksi operator pun dinilai signifikan secara statistik di mana nilai signifikansinya $<\alpha$, yakni 0,003 . Hasil ini sesuai dengan penelitian sebelumnya yang dilakukan oleh Chen (2009) dimana peningkatan PM10 berkorelasi erat dengan penurunan performa kognitif pada orang dewasa di US. ${ }^{[2]}$

Kebisingan akibat kendaraan memiliki hubungan yang positif dengan waktu transaksi operator pintu tol. Kebisingan memiliki nilai koefisien sebesar 0,026 yang artinya setiap pertambahan $1 \mathrm{~dB}$ pada tingkat kebisingan di pintu tol, mengakibatkan kenaikan dalam waktu transaksi sebesar 0,026 sekon. Apabila dilihat dari nilai koefisien beta, kebisingan merupakan faktor lingkungan yang paling tidak signifikan dibandingkan kedua faktor lingkungan lainya karena nilai koefisien beta yang terkecil, sebesar 0,081. Begitu pula terhadap nilai signifikansi statistik, pengaruh dari kebisingan terhadap waktu transaksi operator tidak menghasilkan nilai yang signifikan secara statistik di mana nilai signifikansinya $>\alpha$, yakni 0,553. Hasil tersebut sesuai dengan penelitian yang dilakukan Kempen et al. (2012) dimana peningkatan kebisingan kendaraan berbanding lurus dengan performa kognitif. Namun pada penelitian sebelumnya dikatakan bahwa kebisingan kendaraan memiliki pengaruh yang signifikan terhadap performa. Hal ini dikarenakan penelitian sebelumnya memakan waktu selama 10 bulan yang berbeda jauh dengan penelitian ini yang hanya memakan waktu 2 minggu. Pernyataan ini juga didukung oleh penelitian Ljungberg et al. (2007) dimana penelitian yang relatif sebentar tidak akan memperlihatkan perubahan performa kognitif responden secara signifikan. ${ }^{[9]}$

Whole-body vibration atau getaran seluruh tubuh memiliki hubungan yang positif dengan waktu transaksi operator pintu tol. Getaran memiliki nilai koefisien sebesar 1,467 yang artinya setiap pertambahan $1 \mathrm{~m} / \mathrm{s} 2$ pada tingkat kebisingan di pintu tol, mengakibatkan kenaikan dalam waktu transaksi sebesar 1,467 sekon. Apabila dilihat dari nilai koefisien beta, getaran memiliki tingkat pengaruh kedua yang paling signifikan setelah polusi udara, sebesar 0,108 . Namun, pengaruh dari getaran terhadap waktu transaksi operator tidak menghasilkan nilai yang signifikan secara statistik di mana nilai signifikansinya $>\alpha$, yakni 0,370. Hasil tersebut sesuai dengan penelitian yang dilakukan oleh Ljungberg (2007) dimana semakin besar getaran akan membuat performa kognitif semakin menurun walaupun tidak signifikan secara statistik. Sama halnya dengan kebisingan, nilai getaran yang tidak signifikan ialah akibat jangka waktu penelitian yang sebentar. ${ }^{[4]}$ 


\subsection{Kenyamanan}
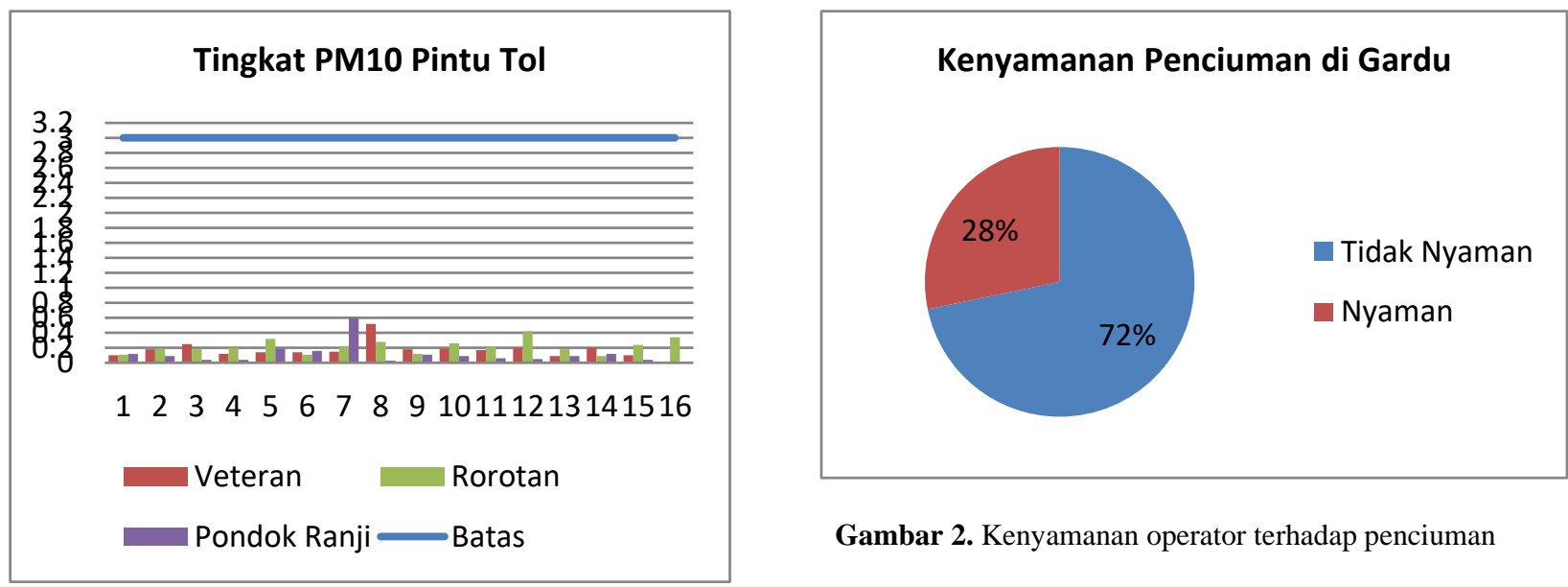

Gambar 2. Kenyamanan operator terhadap penciuman

Gambar 1. Perbandingan tingkat $\mathrm{PM}_{10}$ dengan PERMENA

Gambar 1 menunjukan bahwa dari hasil pengukuran langsung tingkat PM10 yang terdapat di pintu tol jauh di bawah ambang batas yang ditetapkan oleh Peraturan Menteri Tenaga Kerja (PERMENA) sebesar $3 \mathrm{mg} / \mathrm{m} 3$. Hasil kuisioner pada Gambar 2 menunjukkan sebaliknya dimana kebanyakan operator sebanyak 72\% merasa tidak nyaman akibat bau di pintu tol.

Perbedaan antara nilai kuantitatif dan kualitatif disebabkan polusi udara yang dijadikan fokus pada penelitian ini hanyalah PM10 dimana pada kondisi aktual banyak komponen zat lain yang menjadi penyusun dalam pencemaran udara. Menurut Wardhana (2004) dalam bukunya yang berjudul Dampak Pencemaran Lingkungan, perkiraan persentase pencemar udara yang diakibatkan oleh transportasi ditunjukkan pada Tabel 4.

Tabel 4. Komponen pencemaran udara yang dihasilkan mode transportasi

\begin{tabular}{|c|l|c|}
\hline No & Komponen Pencemar & Persentase (\%) \\
\hline 1 & $\mathrm{CO}$ & 70,5 \\
\hline 2 & $\mathrm{NO}_{\mathrm{x}}$ & 8,89 \\
\hline 3 & $\mathrm{SO}_{\mathrm{x}}$ & 0,88 \\
\hline 4 & $\mathrm{HC}($ Hidrokarbon $)$ & 18,34 \\
\hline 5 & Partikel $\left(\mathrm{PM}_{\mathrm{x}}\right)$ & 1,33 \\
\hline
\end{tabular}

Sumber: Wardhana. Dampak Pencemaran Lingkungan 2004

PM10 memiliki persentase kedua terkecil setelah SOx sehingga membuat zat tersebut hanya terdapat sedikit di ambien pintu tol. Oleh karena itu, merupakan hal yang wajar apabila hanya sedikit PM10 yang teridentifikasi di ambien pintu tol.

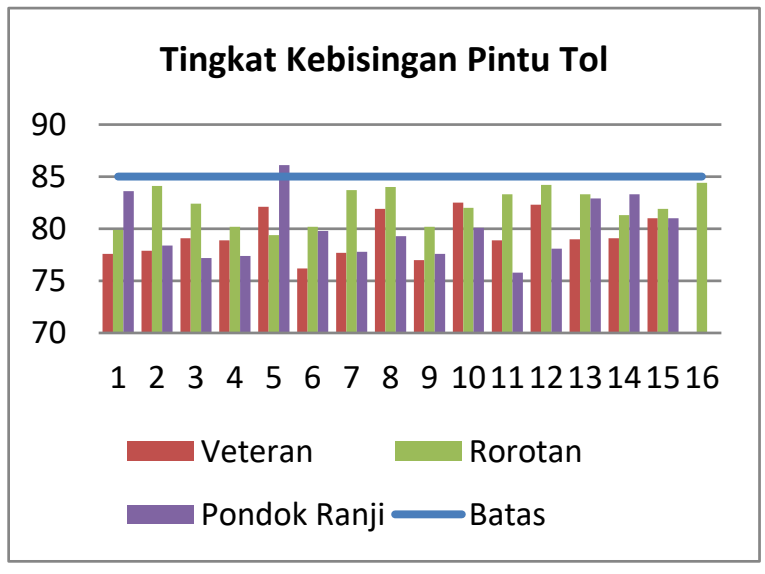

Gambar 3. Perbandingan tingkat kebisingan dengan PERMENA

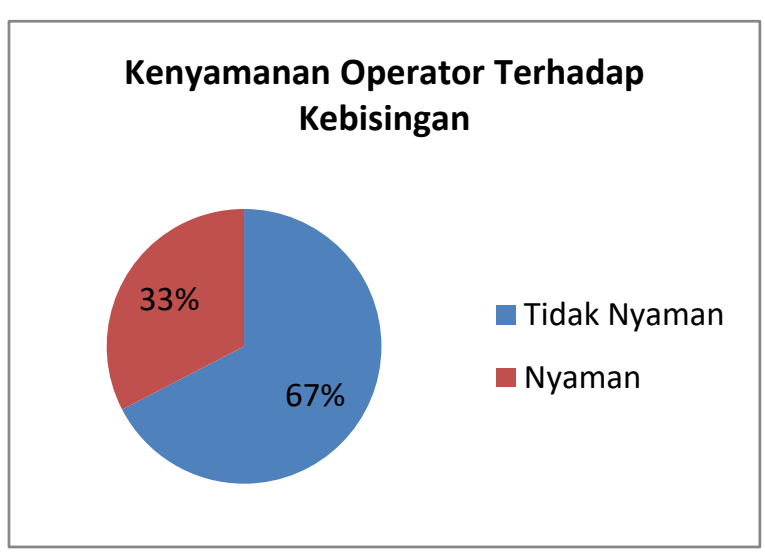

Gambar 4. Kenyamanan operator terhadap kebisingan 
Gambar 3 menunjukkan bahwa tingkat kebisingan berbeda-beda di setiap tol namun masih terdapat di bawah ambang batas kecuali pada satu pengukuran di Pondok Ranji. 67\% operator menganggap bahwa kebisingan yang timbul membuat tidak nyaman seperti pada Gambar 4. Hal tersebut karena intensitas kebisingan yang terdapat di Pondok Ranji dan Veteran dengan nilai rata-rata 79,9 dB dan 79,4 dB berisiko untuk gangguan yang parah. Sedangkan untuk tingkat kebisingan yang berada di Rorotan, nilai 82,2 dB menunjukkan risiko gangguan yang mendalam bahkan menyebabkan tuli seperti yang dideskripsikan Tabel 5. ${ }^{[4]}$

Tabel 5. Tingkat gangguan pendengaran

\begin{tabular}{|l|l|l|}
\hline \multicolumn{1}{|c|}{$\begin{array}{c}\text { Tingkatan Gangguan } \\
\text { Pendengaran }\end{array}$} & \multicolumn{1}{|c|}{ Nilai ISO Audiometris } & \multicolumn{1}{c|}{ Performa } \\
\hline Tidak ada gangguan & $\leq 25 \mathrm{~dB}$ (telinga yang baik) & $\begin{array}{l}\text { Tidak ada, sangat sedikit, gangguan pendengaran. } \\
\text { Dapat mendengar bisikan. }\end{array}$ \\
\hline Sedikit gangguan & $26-40 \mathrm{~dB}$ (telinga yang baik) & $\begin{array}{l}\text { Dapat mendengar dan mengulang kata-kata dalam } \\
\text { suara normal pada 1 m. }\end{array}$ \\
\hline Gangguan sedang & $41-60 \mathrm{~dB}$ (telinga yang baik) & $\begin{array}{l}\text { Dapat mendengar dan mengulang kata-kata } \\
\text { menggunakan suara kencang pada 1 m }\end{array}$ \\
\hline Gangguan parah & $61-80 \mathrm{~dB}$ (telinga yang baik) & $\begin{array}{l}\text { Dapat mendengar beberapa kata ketika diteriakkan } \\
\text { pada telinga yang baik }\end{array}$ \\
\hline $\begin{array}{l}\text { Gangguan mendalam, } \\
\text { termasuk tuli }\end{array}$ & $\geq 81 \mathrm{~dB}$ (telinga yang baik) & $\begin{array}{l}\text { Tidak dapat mendengar dan memahami bahkan } \\
\text { teriakan }\end{array}$ \\
\hline
\end{tabular}

Sumber: WHO. “International Organization for Standardisation, average of 500, 1000, 2000, $4000 \mathrm{~Hz}$ ”. 1991 Pada Gambar 5, tingkat getaran pun masih berada di bawah ambang batas dari yang ditetapkan oleh pemerintah sebesar 0,5 $\mathrm{m} / \mathrm{s} 2$. Berbeda dengan kedua faktor lingkungan lainnya, Gambar 6 menunjukkan bahwa $57 \%$ operator merasa nyaman terkait dengan paparan getaran seluruh tubuh.
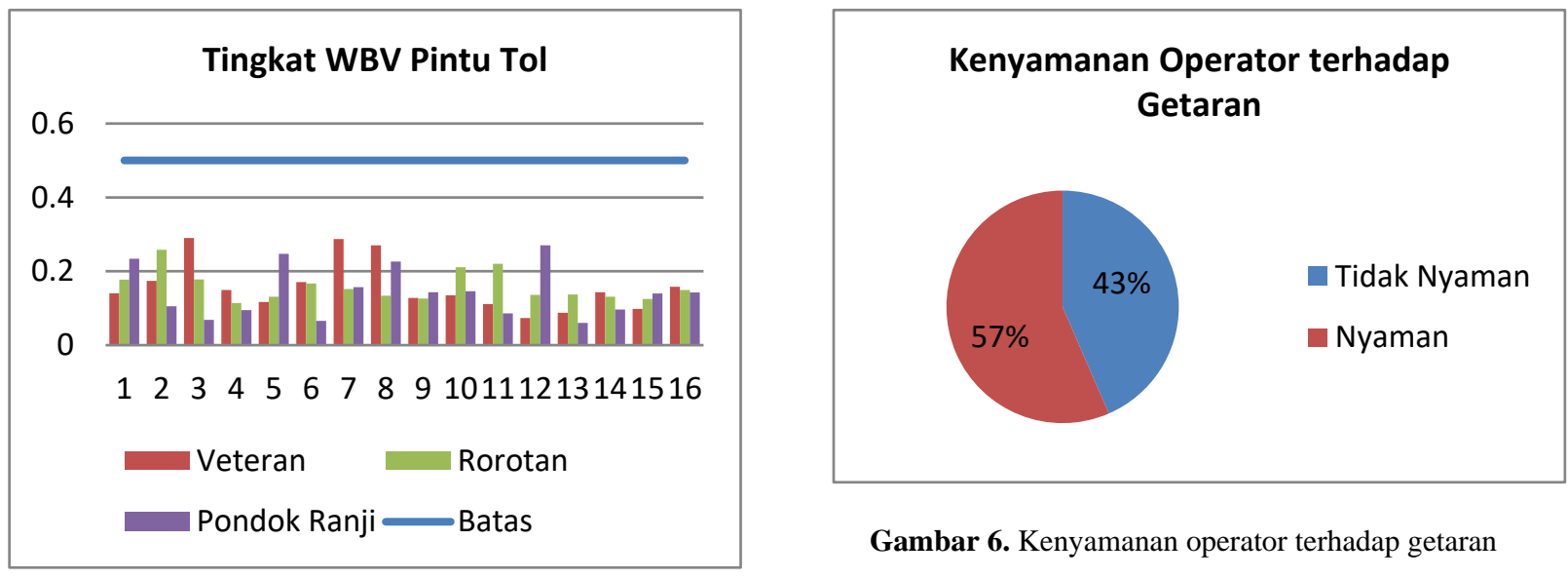

Gambar 6. Kenyamanan operator terhadap getaran

Gambar 5. Perbandingan tingkat getaran dengan PERMENA

Operator pintu tol yang bekerja selama 8 jam akan merasa nyaman apabila besar getaran yang diterima berada pada kisaran comfort level, yakni di bawah $0,315 \mathrm{~m} / \mathrm{s} 2$ seperti pada Tabel 6 . Besar nya getaran di setiap pengukuran yang diterima oleh operator berada di bawah $0,315 \mathrm{~m} / \mathrm{s} 2$ sehingga dapat dimaklumi bahwa operator merasa nyaman. ${ }^{[14]}$

Tabel 6. Pembagian tingkat getaran berdasarkan dampaknya

\begin{tabular}{cccc}
\hline \multirow{2}{*}{$\begin{array}{c}\text { Lama } \\
\text { Pemaparan }\end{array}$} & \multicolumn{3}{c}{$\begin{array}{c}\text { Standar Internasional } \\
\text { ISO 2631-1, 1997 }\end{array}$} \\
\cline { 2 - 4 } & $\begin{array}{c}\text { Likely } \\
\text { health } \\
\text { risk }\end{array}$ & $\begin{array}{c}\text { Caution } \\
\text { zone }\end{array}$ & $\begin{array}{c}\text { Comfort } \\
\text { level }\end{array}$ \\
\hline $8 \mathrm{jam}$ & $0,8 \mathrm{~m} / \mathrm{s}^{2}$ & $0,5 \mathrm{~m} / \mathrm{s}^{2}$ & $0,315 \mathrm{~m} / \mathrm{s}^{2}$ \\
\hline $12 \mathrm{jam}$ & $0,7 \mathrm{~m} / \mathrm{s}^{2}$ & $0,4 \mathrm{~m} / \mathrm{s}^{2}$ & $0,315 \mathrm{~m} / \mathrm{s}^{2}$ \\
\hline \multicolumn{3}{c}{ Sumber: Road safety report }
\end{tabular}




\section{Kesimpulan dan Saran}

\subsection{Kesimpulan}

Pengaruh dari polusi udara, kebisingan, dan getaran terhadap performa operator apabila dilihat dari koefisien atau kemiringannya secara berturut-turut ialah sebesar 1,459, 0,026, dan 1,467. Dari hasil tersebut dapat dilihat bahwa polusi udara memiliki tingkat signifikansi pengaruh terhadap performa tertinggi, diikuti oleh getaran dan kebisingan. Koefisien beta menunjukkan tingkat signifikansi ketiga faktor lingkungan terhadap performa dimana nilai koefisien beta terhadap polusi udara, getaran, dan kebisingan ialah 0,490, 0,108, dan 0,081 secara berturut-turut. Namun hanya polusi udara yang menjadi faktor lingkungan dengan pengaruh paling signifikan secara statistik karena nilai signifikansi nya lebih kecil dari alfa yang ditetapkan yakni 0,003 .

Kebanyakan operator merasa tidak nyaman dengan kadar polusi udara yang terdapat di pintu tol dengan $72 \%$ diantaranya merasa penciuman mereka tidak nyaman dan hanya $28 \%$ yang merasakan nyaman. Terkait kebisingan, operator merasa tidak nyaman dengan tingkat kebisingan yang terdapat di gardu tol dimana $67 \%$ diantaranya merasa tidak nyaman dan $33 \%$ merasa nyaman dengan tingkat kebisingan di gardu.

Berbeda dengan kedua faktor lingkungan yang lain, operator merasa nyaman dengan tingkat getaran di pintu tol. 57\% operator masih merasa nyaman dengan tingkat getaran seluruh tubuh yang terpapar dan hanya $43 \%$ operator yang merasa tidak nyaman.

\subsection{Saran}

Penelitian ini hanya berfokus kepada tiga pintu tol yang terdapat di kawasan tol lingkar luar Jakarta. Akan lebih baik apabila penelitian tidak terbatas di kawasan pintu tol tersebut karena bisa jadi ada pintu tol lain yang memiliki kondisi lingkungan yang lebih buruk. Penelitian ini juga hanya memperhatikan faktor lingkungan (eksternal) sebagai komponen yang mempengaruhi performa dan kenyamanan operator, padahal terdapat faktor lain seperti psikologis operator. Untuk itu, penelitian kedepannya harus juga mempertimbangkan faktor internal dari setiap operator.

Selain itu, faktor polusi udara yang dijadikan tolak ukur pada penelitian ini hanyalah $\mathrm{PM}_{10}$ yang kadarnya terkecil kedua di alam. Penelitian kedepannya akan lebih baik apabila mengukur kadar gas buang dari kendaraan yang memiliki jumlah signifikan di udara bebas, seperti $\mathrm{CO}_{\mathrm{x}}$ atau $\mathrm{NO}_{\mathrm{x}}$.

Keterbatasan lain dalam penelitian ini adalah lamanya waktu pengukuran. Pengukuran performa dalam jangka waktu sebentar tidak akan menunjukkan perubahan yang signifikan, oleh karena itu untuk kedepannya penelitian harus dijalankan dalam jangka waktu setidaknya 1 tahun.

\section{Daftar Pustaka}

[1] Caciari, T., Rosati, M. V., \& Casale, T. (2013). Noise-induced hearing loss in workers exposed to urban stressors. Science of The Total Environment, 302-308.

[2] Chen, J.-C., \& Schwartz, J. (2009). Neurobehavioral effects of ambient air pollution on cognitive performance in US adults. NeuroToxicology, 231-239.

[3] Chiovenda, P., Pasqualetti, P., \& Zappasodi, F. (2007). Environmental noise-exposed workers: Eventrelated potentials, neuropsychological and mood assessment. International Journal of Psychophysiology, 228-237.

[4] Concha-Barrientos, M., Campbell-Lendrum, D., \& Steenland, K. (2004). Occupational Noise. Geneva: World Health Organization Protection of the Human Environment.

[5] Hair, J. R. (2006). Multivariate Data Analysis. Prentice-hall International, Inc.

[6] K., S. P. (1996). Higiene Perusahaan dan Kesehatan Kerja. Jakarta: Gunung Agung.

[7] Lan, L., Lian, Z., \& Pan, L. (2010). The effect of air temperature on office workers' well-being, workload and productivity-evaluated with subjective ratings. Applied Ergonomics, 29-36.

[8] Lavy, V., Ebenstein, A., \& Roth, S. (2012). The impact of air pollution on cognitive performance and human capital formation.

[9] Ljungberg, J. K., \& Neely, G. (2007). Stress, subjective experience and cognitive performance during exposure to noise and vibration. Environmental Psychology, 44-54.

[10] Nagano, K., \& Horikoshi, T. (2005). New comfort index during combined conditions of moderate low ambient temperature and traffic noise. Energy and Buildings, 287-294. 
[11] Now, A. (n.d.). Particle Pollution (PM10) and (PM2.5). Retrieved April 9, 2014, from AirNow: http://www.airnow.gov/index.cfm?action=aqibasics.particle

[12] Organization, W. H. (2014, March). Ambient (outdoor) air quality and health. Retrieved April 9, 2014, from WHO: http://www.who.int/mediacentre/factsheets/fs313/en/

[13] OSHA. (2010, February 9). Instrument used to conduct a noise survey. Retrieved April 10, 2014, from Occupational \& \& Health Administration: https://www.osha.gov/dts/osta/otm/noise/exposure/instrumentation.html

[14] Paschold, H. W. (2008, June). Occupational Hazards Whole-body Vibration. Retrieved April 10, 2014, from Professional Safety: http://www.asse.org/professionalsafety/pastissues/053/06/PascholdFeature_0608.pdf.

[15] Pemerintah. (1990). Peraturan Pemerintah Republik Indonesia (PP) No. 8. BPHN.

[16] Pradhan, A. C., Swain, B. K., \& Goswami, S. (2012). Road traffic noise assessment and modeling of Sambalpur City, India: A comprehensive, comparative, and complete study . Ecophysiological Occupational Health, 51-63.

[17] RI, M. T. (2011). Peraturan Menteri Tenaga Kerja dan Transmigrasi Nomor Per. 13/Men/X/2011 Tahun 2011 mengenai Nilai Ambang Batas Faktor Fisika dan Faktor Kimia di Tempat Kerja. Jakarta: Menteri Tenaga Kerja dan Transmigrasi RI.

[18] Rowan, M. P., \& Wright, P. C. (1994). Ergonomics is good for business. Work study, 7.

[19] Shikdar, A. A., \& Sawaqed, N. M. (2003). Worker productivity, and occupational health and safety issues in selected industries. Computer \& industrial engineering, 563-572. 1

[20] Slota, G. P. (2012). Effects of seated whole-body vibration on spinal stability control. United States: ProQuest.

[21] Stanton, N., Hedge, A., Brookhuis, K., Salas, E., \& Hendrick, H. (2005). Handbook of Human Factors and Ergonomics Method. Washington D.C: CRC Press.

[22] Umun, M. P. (2005). Peraturan Menteri Pekerjaan Umum No.: 392/PRT/M/2005 tentang Standar Pelayanan Minimal Jalan Tol. Jakarta: Menteri Pekerjaan Umum.

[23] WSDOT. (2012, January 1). Traffic noise. Retrieved April 9, 2014, from Washington State Department of Transportation: http://www.wsdot.wa.gov/environment/air/trafficnoise.htm 